\title{
Simulation Learning Model to Improve the Understanding of Land Disaster Mitigation Materials of 2013 Curriculum Geography High School State 12 Semarang
}

\author{
Andi Irwan Benardi ${ }^{1}$, Ananto Aji ${ }^{2}$, Ariyani Indrayati ${ }^{3}$, Ashabul Kahfi ${ }^{4}$ \\ \{andi@mail.unnes.ac.id ${ }^{1}$, ajiananto@mail.unnes.ac.id ${ }^{2}$, ariyani.ideas@gmail.com ${ }^{3}$, \\ ashabulkahfi@students.unnes.ac.id $\left.{ }^{4}\right\}$ \\ 1,2,3,4 Universitas Negeri Semarang, Indonesia
}

\begin{abstract}
High School State 12 Semarang is in Plalangan Village which is one of the villages with a high vulnerability to landslides in Gunungpati District, Semarang City. Students need knowledge about prevention and preparedness, in order to reduce the impact of landslides. This study aims to determine the learning process of landslide risk reduction, find out student responses to landslide simulations, and find out the difference between learning outcomes for students who get learning using disaster simulation with students who get learning without using simulation. This study uses a quasi-experimental research design, using quantitative analysis in the form of percentage calculations and analysis of independent test samples t-test. The results of the t-test showed that there were differences in student learning outcomes between students who received learning using disaster simulation with students who received learning without using disaster simulation. Thus, learning using disaster simulation is better than learning by not using disaster simulation, meaning that disaster simulation can be used as an alternative learning method in learning to reduce landslide risk in the city of Semarang.
\end{abstract}

Keywords: Simulation, Disaster Mitigation, Landslides.

\section{Introduction}

Indonesia is located at the confluence of three world plates namely the Eurasian plate, the Pacific plate, and the Australian plate which is always moving and pounding each other. The consequence of the collision is the formation of volcanic lines in Indonesia. The existence of this volcanic pathway has caused mountains and hills to form in some regions of Indonesia with steep slope slopes. This condition causes Indonesia to have the potential for landslides that can cause casualties, property losses and environmental damage. This natural condition is further aggravated by the existence of environmental damage in the form of conversion of vegetated land to cultivated land or even become non-vegetated land. In the end, this causes an increase in vulnerability and frequency of natural disasters, including landslides (BNPB, 2018). 
The learning process requires positive interaction between the teacher and students, so that two-way communication will manifest in a conducive atmosphere and a balance between the freedom of students to express their feelings with the authority of the teacher (Sholeh, 2007: 129). The student center learning process will be able to make students more active in participating in class because in class learning is not only a teacher who can convey knowledge to students, but students can also express opinions regarding knowledge or experience according to learning that being studied. Then students can also practice directly about the understanding that has been learned before by implementing it directly in everyday life, so that students can learn cognitively, affective and psychomotor. The problem in studying geography subject matter is knowledge that is still considered difficult to understand because it only studies theory without implementing it, so that it causes students to confuse learning geography because they have not been able to harmonize knowledge in theory through direct simulation. The main material that requires simulation is mitigation and adaptation to natural disasters.

He location of the study was in High School State 12 Semarang. The researcher took the location in this school because High School State 12 Semarang was in the area adjacent to the slopes of Mount Ungaran which is one of the landslide prone areas in the city of Semarang. In each rainy season there is often a disaster of land movement either by cutting down rivers, road cliffs or hill cliffs that surround the village.

The Government carried out the implementation of Disaster Risk Reduction (PRB) with the legal basis of Republic of Indonesia Law number 24 of 2007 concerning 'Disaster Management'. The existence of Republic of Indonesia Law No. 24 of 2007 has changed the mindset of disaster management into disaster management which focuses more on efforts before a disaster strikes. Disaster management is not only oriented during emergency response, but is carried out before (pre-disaster), in the event of a disaster and after (post-disaster). The Community Preparedness Study that has been carried out in various regions shows the low level of preparedness of the school community compared to the community as well as the LIPI apparatus (2006-2007) in the Curriculum Center (2009). This is very worrying because schools are the basis of a community of children who are vulnerable groups that need to be protected and at the same time need to improve their knowledge and skills (Center curriculum, 2009).

Based on the initial interview conducted with the geography teacher at Semarang 12 High School, the learning patterns used still tend to involve less optimal student learning activeness. The use of package books is dominated by subject matter in the form of text and power points in the learning process. They also stated that students often pay less attention to the learning process which is suspected because geography is considered boring and unpleasant. Simulation method is a form of practice method that is nature to develop student learning skill (mental and physical / technical skills). This method moves a real situation into an activity or study room because of the difficulty of practicing in a real situation. For example: before practicing an accident aid, a school student performs an accident simulation first (not really an accident or injured). The situation encountered in this simulation must be made as it really is the real situation (replication of reality). Another example, in a facilitation training, a participant simulates a learning method as if doing it with his mentoring group. Other facilitators act as assisted groups that will really be found in the participants' daily lives (farmer mother, farmer father, group administrator, etc.). In the second example, this method is indeed similar to role playing. But in the simulation, participants play more roles as themselves when carrying out an activity / task that they will actually do. 
This study aims: (1) to know the learning process of landslide risk reduction, (2) to find out student responses to learning using disaster simulation, (3) to know the differences in student learning outcomes between students who receive learning using disaster simulation with students who receive learning not using the simulation method. The importance of knowledge about landslide risk reduction material for students who are in the location of landslide-prone areas, with the simulation method as a learning media that has the potential to improve student learning outcomes, researchers are interested in conducting further studies on landslide risk reduction learning with using disaster simulation at Semarang 12 High School.

\section{Method}

The research design used was experimental research. The variables in this study are as follows. (1) The independent variable for the experimental group is the learning process of landslide risk reduction using disaster simulation, while the independent variable for the control group is the learning process of landslide risk reduction using conventional media. (2) The dependent variable for the experimental class and the control class is the same, namely: student learning outcomes.

The data analysis method used in this study is a quantitative method. The data analysis used is percentage descriptive statistics and parametric inferential statistics, namely independent samples t-test. Percentage descriptive statistics are used to find out the learning process and student responses to learning and student affective learning outcomes. While parametric inferential statistics, namely the independent samples t-test test, are used to determine whether there are differences in student learning outcomes between students who receive learning using disaster simulations and students who receive learning do not use disaster simulations.

\section{Results And Discussion}

The data obtained in the field research were reviewed in accordance with the formulation of the problem and then related to the theory that has been stated. Based on observations, questionnaires, and tests then proceed with data analysis. Learning about landslide risk reduction using disaster simulation for students at 12th High School Semarang can be discussed as follows.

\subsection{Learning Process Landslide Disaster Risk Reduction}

Based on the overall students who took part in the learning process showed the learning activeness of the experimental class students with a percentage of $82 \%$ and included in the active learning criteria of students. This shows that the activity of seeing, speaking, listening, writing, and attitude in the experimental class is included in the active criteria. Whereas all students who took part in the learning process showed the learning activeness of control class students with a percentage of $79 \%$ and included in the active learning activeness criteria of students. This shows that the activity of seeing, speaking, listening, writing, and attitude in the control class is included 
in the active criteria. So, in this study the learning activeness of the experimental class students was greater than the control class $(82 \%>79 \%)$. This shows that the study of landslide risk reduction using disaster simulation further increases student learning activeness rather than landslide risk reduction learning by not using disaster simulation.

Ased on the observations of the entire observer who assessed the researcher, namely Mr. Karyono, M.Pd., the experimental class learning showed the performance of the teacher in learning with the percentage of $88 \%$ and included in the teacher's performance in learning criteria. This shows that the teacher's performance in pre-learning, opening lessons, core activities, and closing at the first meeting and meeting II are included in the criteria of good. Based on the overall observer who assessed the researcher, namely Mr. Karyono, M.Pd., the control class learning showed the teacher's performance in learning with a percentage of $84 \%$ and included in the teacher's performance in learning criteria. This shows that the teacher's performance in prelearning, opening lessons, core activities, and closing at the first meeting and meeting II are included in the criteria of good. So, in this study the teacher's performance in the experimental class learning was greater than the control class $(88 \%>84 \%)$.

It was concluded that the learning process in this study in the experimental class and the control class which was seen from student learning activeness and teacher performance in learning were both active and good criteria, but there were differences in percentage scores namely the active learning of the experimental class students better than the control class $(82 \%>79 \%)$ and the teacher's performance in learning was better than the control class $(88 \%>84 \%)$.

The success of the teaching process is largely influenced by the variables that come from the students themselves, the efforts of the teacher in providing and creating teaching conditions, as well as environmental variables, especially the means and climate that are adequate for the growth of the teaching process. The integration of the three variables above is the key to the success of teaching in terms of the process (Sudjana, 2010). Variables that come from students themselves in this study are seen from student learning activeness. Teacher variables are seen from the teacher's performance in learning.

This illustrates that there is already clear communication between teachers (instructors) with students (students), so that the two activities are integrated, namely teaching activities (teacher efforts) with learning activities (student assignments) that are effective in achieving teaching goals. Communication that is used to develop dynamic interactions between teachers and students is many-way communication or communication that does not only involve students' dynamic interactions between teachers and students but also involves dynamic interaction between one student and another student. The teaching and learning process with communication patterns develops optimal student activities, so that students grow active learning, discussion is a strategy that can develop communication.

\subsection{Student responses to learning using disaster simulation}

Based on data from all students who filled out student responses to learning questionnaires showed a response with a percentage of $83 \%$ and table 1 normalized gain test results included in the criteria well. This shows that students feel the learning process, the use of disaster simulations, material descriptions, teacher performance in learning, environmental use, learning process evaluation activities are included in the criteria of good. 
Simulation learning methods are used in accordance with procedures and systematically so students will not be confused in applying them. The researcher used the theme of disaster, namely earthquake in accordance with the subject matter being taught. The implementation of simulation learning methods is taught systematically and gradually so that students can understand in depth about how to deal with earthquake disasters, especially in schools. The implementation of simulation learning methods involves researchers, geography subject teachers, UKS management teachers, PMR organizations, office boys, and security guards. Simulation learning methods cannot be carried out alone by researchers because they require infrastructure, activity permits, and security during earthquake disaster mitigation simulation activities.

\subsection{Difference between Learning Outcomes for Students Using Disaster Simulation with Students Who Don't Use Disaster Simulation}

In the pre test value, after the normality and homogeneity test and the independent t-test, the results obtained were in the experimental class and control class showed no significant differences. This means that in the experimental class and control class there is no difference in initial performance in landslide risk reduction material.

After the normality test, homogeneity test and independent samples t-test, it is known that $\mathrm{t}$ count $>t$ table $(2.160>2.004)$ then Ho is rejected, so the conclusion is that there are differences in the average test scores between the experimental class and the control class. The mean value of the experimental class is 81.29 while the control class is 77.86 . So the experimental class has a higher test value than the control class.

Table 1. The Results Of The Normalized Zain Test

\begin{tabular}{ccccc}
\hline \multirow{2}{*}{ Information } & \multicolumn{2}{c}{ Experiment Class } & \multicolumn{2}{c}{ Control Class } \\
\cline { 2 - 5 } & Pre Test & Post Test & Pre Test & Post Test \\
\hline Total Students & \multicolumn{2}{c}{28} & & 28 \\
\hline Average Value & 65,29 & 81,29 & 64,86 & 77,86 \\
\hline Lowest value & 36 & 68 & 40 & 60 \\
\hline Top Value & 88 & 92 & 88 & 92 \\
\hline$<\mathrm{g}>$ & \multicolumn{2}{c}{0,46} & \multicolumn{2}{c}{0,37} \\
\hline Criteria & \multicolumn{2}{c}{ moderate } & \multicolumn{2}{c}{ moderate }
\end{tabular}

Source: Research Data, 2019

In table 1 the results of the normalized zain test are known that the results of an increase in the difference between post-test and pre-test (N-Gain) learning outcomes of landslide risk reduction material in the experimental class and the control class. The experimental class produces an average gain value higher than the control class which is 0.46 while the control class is 0.37 , although according to Meltzer (2002) the results are both in the criteria of being. The results of the experimental class which are both in the moderate criteria and not in the high criteria, this may be in line with the students' response to landslide risk reduction learning on the questionnaire, namely the indicators of the use of disaster simulation shows that the value of $76 \%$ is quite good. In the 
student descriptor felt the appearance (illustration, picture, sound, writing) in the disaster simulation was clear to be understood in geography learning landslide risk reduction material showed 1 student (4\%) responded well and 23 students $(82 \%)$ responded quite well and 4 students (14\%) responded badly.

Table 2. Classical Student Completeness

\begin{tabular}{lcccl}
\hline \multicolumn{1}{c}{ Class } & $\begin{array}{c}\sum \text { student } \\
\text { scores }>73\end{array}$ & $\begin{array}{c}\sum \text { Total } \\
\text { Students }\end{array}$ & $\begin{array}{c}\text { Classical } \\
\text { Completeness }\end{array}$ & Criteria \\
\hline Experiment & 25 & 28 & $89,28 \%$ & Complete \\
Control & 24 & 28 & $85,71 \%$ & Complete \\
\hline
\end{tabular}

Source: Research Data, 2019

In table 2 the classical completeness of students is known that in the experimental class and the control class with classical completeness $89.28 \%$ and $85.71 \%$ both in the complete criteria, so that classical completeness has been achieved. In other words, landslide risk reduction learning works well in the experimental class that uses disaster simulations and control classes that do not use disaster simulations.

Student learning outcomes show there are differences in the average test scores between the experimental class and the control class, the mean value of the experimental class is 81.29 while the control class is 77.86 . So the experimental class has a higher test value than the control class and by using disaster simulation students are better able to improve learning outcomes.

Affective learning outcomes are changes that result in human change in attitude and behavior. Changes in attitude in this study were examined in the affective domain. Of all students who took part in the study showed the experimental class affective learning outcomes with a percentage of $85 \%$ and included in the criteria for good affective learning outcomes. This shows that students have an attitude of discipline, respect, attention, diligence, responsibility, accuracy in good criteria. While all students who took part in the learning process showed control class affective learning outcomes with a percentage of $81 \%$ and included in the criteria of good affective learning outcomes. This shows that students have an attitude of discipline, respect, attention, diligence, responsibility, accuracy in good criteria. So, in this study the experimental class affective learning outcomes were greater than the control class $(85 \%>81 \%)$. This shows that landslide risk reduction learning by using disaster simulation further enhances student affective learning outcomes rather than landslide risk reduction learning with conventional media, namely power point media.

Learning outcomes with cognitive aspects were measured using a test instrument consisting of 30 multiple choice questions. Analysis of learning outcomes between the experimental class and the control class has clear differences when students answer the problem of mitigation stages during disasters and post-disaster. The experimental class answers more questions correctly than the control class, such as the example problem as in number 17, which is the question of the basic colors used to make the evacuation track board. The experimental class has implemented the prestage natural disaster mitigation simulation by making an evacuation track board so that all students know the answers to the items in question. Then 19, the example of the test question is asking about disaster mitigation steps when on the 2nd floor. Experimental classes have been taught how to implement landslide disaster simulations if they are on the 2nd floor. 
Affective learning outcomes (attitudes) of the experimental class are higher than the control class. The criteria for the experimental class affective learning outcomes were very high, while the control class was included in the medium criteria. The difference in descriptive scores is the percentage of affective learning outcomes which reached 30.98\%. Factors that influence the differences in learning outcomes are in the implementation of learning methods used by researchers. The experimental class has higher learning outcomes because it carries out simulations that can shape and improve attitudes in earthquake disaster mitigation. Attitude learning results were measured using questionnaire instruments, in the questionnaire there were criteria and scores, namely (1) Unskilled, (2) Less skilled, (3) Self-skilled, (4) Skilled, (5) Very skilled. The total score of the experimental class is 5986 out of 37 students, while the control class has a score of 3981 out of 34 students. The experimental class affective (attitude) results were superior to the control class supported by teaching and learning activities carried out by researchers. Supporting factors such as knowing and participating in making documents needed in earthquake disaster mitigation simulations, carrying out action plan activities to be carried out in schools, and complying with procedural regulations during the simulation activities. So that most students in the experimental class answer the questionnaire with answers (5) Very skilled, while students in the control class mostly answer by choosing (3) Quite skilled because students are not taught simulation or practice directly about attitudes that must be implemented in earthquake disaster mitigation earth.

Psychomotor learning outcomes (actions) are measured using a questionnaire instrument. The score criteria used are the same as attitude measurements. Questionnaire for psychomotor learning outcomes (actions) has 4 indicators. The experimental class has a total score of 4607 from 37 students, while the control class has a total score of 3132 out of 34 students. Psychomotor learning outcomes (actions) between the experimental class and the control class have a percentage difference that is almost the same as the affective learning outcome (attitude). The difference in learning outcomes in the two classes is because students in the experimental class as a whole have been taught about mitigation measures to mitigate the risk of earthquake disasters in schools starting from the pre, current and post-disaster stages. Students in the experimental class have participated in a series of activities for 3 core meetings so that they understand and know how to practice it according to the theories that have been learned.

This is in accordance with the opinion of Indrayati and Setyaningsih (2017: 192) that in essence all things, both concrete and non-concrete, can be used as sources in the learning process. Learning in essence is a process of change in someone. This change is due to an experience. Human experience can be divided into two types, namely: direct experience and indirect experience. In direct experience children experience and act alone directly, for example learning to sew, hoeing dancing, and others. The child does the action himself in the real situation. Such experience will bring better results. However, not all problems can be learned directly by humans, even in general or most are learned through indirect experience. Indirect experience is obtained in various ways, one of which is observing the symptoms or situations using sensory devices, namely watching disaster simulations.

Some obstacles that arise in learning activities with disaster simulation during the research activities take place from the results of observations in the field, it can be seen that the material presented in general has fulfilled the expected learning objectives. Nevertheless, students want a more interactive storyline and contain examples of real activities that are more related to the 
material discussed. This is related to the expectations of students so that they can have more insight and knowledge so that their understanding of related concepts can become more comprehensive.

The application of lecture learning methods with simulations affects student learning outcomes in understanding the subject matter of natural disaster mitigation and adaptation on geography subjects. The influence of simulation learning methods on the subject matter of mitigation and adaptation to natural disasters can affect the improvement of student learning outcomes. The effect of the earthquake simulation learning method can be observed from the higher student learning outcomes of the experimental class compared to the experimental class. The experimental class can be higher learning outcomes because it is influenced by the learning methods applied by researchers, while the control class uses conventional methods. The effect of the earthquake simulation learning method has a positive effect because it can improve student learning outcomes, so the simulation learning method is used correctly in the subject matter of natural disaster mitigation and adaptation in class XI.

Simulation learning methods have advantages compared to conventional learning methods applied by teaching teachers in the control class. The advantage of simulation learning methods in the subject matter of natural disaster mitigation and adaptation is that students directly practice or simulate directly with existing theories. Then students are also more active in geography learning activities, then students can remember the subject matter while practicing directly.

\section{Conclusion}

Based on the results of the research and discussion of landslide risk reduction learning using disaster simulation for students in State High School 12 Semarang. Then conclusions can be obtained as follows. First, the learning process in this study is seen from student learning activeness and teacher performance in learning. The learning process in the experimental class or learning by using disaster simulation and control class or learning by not using disaster simulation is seen from student learning activeness and teacher performance in learning both in active and good criteria, but there are differences in the average percentage where learning activeness the experimental class students were more active than the control class and the teacher's performance in learning was better than the control class. Second, from all students who filled out student responses to learning questionnaires showed responses with percentages into good criteria. This shows that students feel the learning process, the use of disaster simulations, material descriptions, teacher performance in learning, environmental use, learning process evaluation activities are included in the criteria of good. Third, learning outcomes for students using disaster simulation with learning outcomes of students who do not use disaster simulation after normality tests, homogeneity tests and independent samples t-test tests are known that there are differences in the average test scores between the experimental class and the control class. The mean value of the experimental class is greater than the control class. So landslide risk reduction learning using disaster simulation further improves student learning outcomes rather than the usual learning of landslide risk reduction.

Based on the results of research and discussion, the researcher provides suggestions to improve student learning outcomes as follows. First, the use of disaster simulations in landslide 
risk reduction learning can improve the learning process and learning outcomes, so learning using disaster simulations can be used in landslide risk reduction learning. Second, it is hoped that further development of the quality of disaster simulations, both concerning the design of the disaster simulation display, as well as the quality of the material needed by students in it. Third, the use of the Learning Module for Integrating High School Risk of Landslide Reduction made by the Curriculum Center of the Research and Development Agency of the Ministry of National Education can be used as a guide for integrating landslide risk reduction in learning, especially geography lessons. fourth, schools are expected to be able to integrate structured and sustainable learning of landslide risk reduction from class X, XI, and XII.

\section{References}

Badan Nasional Penanggulangan Bencana. 2017. Buku Pedoman Latihan Kesiapsiagaan Bencana Membangun Kesadaran, Kewaspadaan, dan Kesiapsiagaan Dalam Menghadapi Bencana. Jakarta: BNPB.

Indrayati, Ariyani dan Setyaningsih, Wahyu. 2017. Karakteristik Air Tanah Di Sekitar Rawa Jombor, Klaten dan Potensinya Sebagai Sumber Belajar geografi Di Lapangan. Jurnal geografi, 13 (2): 192-224.

Meltzer, D. F. 2002. The Relationship between Mathematics Preparation and Conceptual Learning Gain in Physics. American Journal of Physics. Vol. 70 page. 1259-1268.

Pusat Kurikulum. 2009. Modul ajar pengintegrasian Pengurangan Risiko Longsor (Bahan pengayaan bagi Guru SMP/MTS). Jakarta: Kementerian Pendidikan Nasional.

Rahmatullah, Muhammad. 2011. Pengaruh pemanfaatan media pembelajaran simulasi bencana terhadap hasil belajar (Studi Eksperimen pada Mata Pelajaran GEOGRAFI Siswa Kelas VII SMPN 6 Banjarmasin). ISSN. No.178-186.

Sadiman, Arief S.dkk. 2008. Media Pendidikan: Pengertian, Pengembangan, dan Pemanfaatannya. Jakarta: PT Raja Grafindo Perkasa.

Setyowati, dkk. 2017. Panduan Pengurangan Risiko Bencana (PRB) Sekolah. Semarang: Swadaya Manunggal.

Sholeh, Muh. 2007. Perencanaan Pembelajaran Mata Pelajaran geografi Tingkat SMA Dalam Konteks KTSP. Jurnal geografi FIS UNNES, Volume 4 No.2: 129-137.

Sugiyono, 2010. Metode Penelitian Pendidikan Pendekatan (Kualitatif, kuantitatif dan R\&D). Jakarta: Alfabeta.

Sukmaniar, Ngadino, Karsono. 2013. Peningkatan Ketrampilan Menulis Narasi dengan Menggunakan Media Pembelajaran Simulasi bencana. Jurusan PGSD. FKIP. Universitas Sebelas Maret 